\title{
The Seabed in the High North - How to Address Conflicts?
}

\author{
Alexander S. Skaridov
}

\section{Introduction}

A general question underlying current competing state interests in the Arctic is whether claims to the Arctic continental shelf are justified by existence of potential resources. Indeed, the assumption that a significant proportion of the world's undiscovered oil and gas deposits lie beneath the Arctic seabed have turned the Arctic into a region of considerable geopolitical interest. However, geological investigations cover just small Arctic seabed areas; all other estimations are based on mathematic and methods of probabilistic modelling.

For the purpose of this chapter, we present estimations made by U.S. Geological Survey (USGS) which were based on a geological probabilistic methodology. The USGS estimated the deposits of undiscovered oil and gas in 33 geologic provinces that thought to be prospective for petroleum. The sum of the estimates for each province indicates that 90 billion barrels of oil, 1,669 trillion cubic feet of natural gas, and 44 billion barrels of natural gas liquids may remain to be found in the Arctic, of which approximately $84 \%$ is expected to be found in offshore areas. ${ }^{1}$ Another popular speculation regarding the Arctic is that, because of the changing climate of the Arctic, ice cover will reduce in the near future and most spaces of the Higher North will be available for normal navigation, which will dramatically influence the global shipping. ${ }^{2}$

Meanwhile, the UsGs study, like other ones, is limited in its knowledge basis and method, also because of the geographical limitation of the seabed areas which were studied and their depth. ${ }^{3}$ That is why, in our view, present

1 U.S. Department of the Interior, U.S. Geological Survey, 'Circum-Arctic Resource Appraisal: Estimates of Undiscovered Oil and Gas North of the Arctic Circle,' USGS Fact Sheet 20083049. Available at: <http://pubs.usgs.gov/fs/2008/3049/fs2008-3049.pdf >.

2 The third of the Arctic Ocean is covered with old ice, the surface of newly-formed ice is changing from year to year, and from measurement season to season; furthermore, there is a lot of data that the surface of newly-formed ice can enlarge.

3 In the USGS study, were included only those stocks that are considered to be recoverable using existing technology, even in conditions of permanent ice cover and depth of about $500 \mathrm{~m}$. 
aspirations of coastal countries to divide the Arctic spaces are not very much related to current scientific knowledge about seabed resources. All our further conclusions in this chapter will be made on the grounds that the abovementioned statements do not have sufficient scientific proof and cannot be taken as a major challenge to the issue of the delimitation of the Arctic seabed. What is more important are the facts that only few nations ${ }^{4}$ own the Arctic coast, and, because of this, those states have a much higher responsibility in the protection of Polar spaces than other states.

Another obvious consideration is that coastal economy attracts more and more resources, and its value is significantly increasing, which at the national level requires different conditions for investment and due consideration to the people living in the Arctic regions and who consider themselves indigenous. ${ }^{5}$

Certainly, the assumption that Arctic resources potential is exaggerated is not a strong enough argument to stop the process of establishing the boundaries and delimitation of the seabed. However, the desire to establish the boundaries far beyond the real possibilities of operation is in stark contrast with the simplicity and clarity of existing international legal norms regulating the delimitation and the legal regime of Arctic spaces.

This chapter explores the question of delimitation of jurisdiction in the Arctic as a fundamental starting point for discussing the regime for exploration for and exploitation of seabed resources in an area of the world which is subject to competing state and commercial interests, and so to potential conflicts. It starts by a brief historical sketch of countries claims to the Arctic seabed (Section 2), before considering the respective ambitions and so conflicting interests of the Arctic states (Section 3). The chapter ends with a reflection on possible ways of resolving disputes (Section 4).

\section{Delimitation and Competing Claims over the Arctic Seabed}

\subsection{Application of UNCLOS Provisions}

At least two key issues should be raised here: the applicability of the provisions of the 1982 UN Law of the Sea Convention (UNCLOS), and the legitimate access to Arctic resources by non-Arctic states. ${ }^{6}$

4 Russian Federation and Canada own $80 \%$ of the Arctic coastal area, Norway and Denmark about $16 \%$, the USA $4 \%$.

5 For example, for Russia comprises nearly $20,000 \mathrm{~km}$ of state border, about $11 \%$ of national income. Considerable amount of hydrocarbon and other minerals are already extracted there. It is the center of shipbuilding with ports and port stations.

6 In this chapter, we are not going to cover the last point since it needs a separate study. 
From our point of view, the attempts of many scholars and official commentators to build up various concepts of extension of special rights (within national jurisdiction) on regulation the exploitation of the resources of the Arctic shelf and transport of goods based on the provisions of Article 234 UNCLOS (Ice covered areas) cannot be considered reasonable. This Article in UNCLOS does not deal with exclusive 'Arctic reference' (we can find 'ice covered areas' in other parts of the World ocean), and contains the terms which are not determined by the Convention, but which are key for the application of the UNCLOS. For instance, it is not obvious what to perceive by 'severe climate conditions', 'serious damage to ecological balance'.

It is the view of the author that the application of the UNCLOS provisions to the Polar regions without taking into consideration their peculiarities, will contradict the natural conditions of the environment. As a matter of fact, we cannot consider the icefield as an area of normal navigation, as well as define baselines to determine the outer limits of the territorial sea or other spaces if an island or a part of land which are surrounded by permanently frozen areas, such as icefront, grounded ice or grounded hummock. In other words, equating the Arctic Ocean without regard to the physical condition of the environment to any other area of the ocean does not add the natural grounds for the resolution of present and future delimitation. The preparatory documents analysis of UNCLOS gives evidence that the negotiators did not want to make all process of negotiations still more complicated and discuss such a difficult matter from the point of view of law.

\subsection{Position of the Five Arctic Coastal States (Ilulissat Declaration) and Continental Shelf Delineation}

On May 28, 2008 in Ilulissat in Greenland, the five Arctic coastal states (A-5) ${ }^{7}$ adopted a declaration where they recall that an extensive international legal framework applies the law of the sea to the Arctic ocean which provides for important rights and obligations concerning the delineation of the outer limits of the continental shelf, the protection of the marine environment, including ice-covered areas, freedom of navigation, marine scientific research, and other uses of the sea. The countries stated that they remained committed to this legal framework and to the orderly settlement of any possible overlapping claims. The A-5 see no need to develop a new comprehensive international legal regime to govern the Arctic Ocean. ${ }^{8}$

7 A-5 is the short name for the five Arctic coastal states: Denmark, Canada, Norway, Russia and USA.

8 The Ilulissat Declaration, Arctic Ocean Conference, Ilulissat, Greenland, 27-29 May 2008. Available at: <http://www.arcticgovernance.org/the-ilulissat-declaration.4872424.html >. 
Canada, Denmark, ${ }^{9}$ Norway and Russia ratified the UnCLOs, ${ }^{10}$ while the United States of America is still working on it. Each A-5 country claimed exclusive economic zones (EEZ) of 200 nautical miles (nm), and continental shelf areas adjacent to their coasts.

The definition of the continental shelf and the criteria by which a coastal State may establish the outer limits of its continental shelf are set out in UNCLOS, Article 76. In addition, the Third United Nations Conference on the Law of the Sea adopted on 29 August 1980 a Statement of Understanding which is contained in Annex II to the Final Act of the Conference. ${ }^{11}$

Pursuant to Article 76(7) UNCLOS, information on the limits of the continental shelf (CS) beyond $200 \mathrm{~nm}$ from the baseline from which the breadth of the territorial sea is measured shall be submitted by the coastal State to the Commission on the Limits of the Continental Shelf (CLCS) set up on the basis of equitable geographical representation. The Commission shall make recommendations to coastal States on matters related to the establishment of the outer limits of their continental shelf. It is essential to stress that the limits of the shelf established by a coastal State on the basis of CLCS recommendation will be final and binding only after adoption by the coastal states.

Article 76 uses two different terms in the meaning of the description of the boundaries: 'delineation' and 'delimitation' The first one refers to the line which should be determined by the coastal state as the outermost points of the continental margin to a distance drawn according to UNCLOS. ${ }^{12}$

The UNCLOS requirements concerning deposit of, and publication of the charts or lists of geographical coordinates showing the outer limits of the CS practically remained unfulfilled and experts, for visualization of the Arctic

$9 \quad$ Via Greenland. Denmark's sovereignty over all of Greenland was recognized by the United States in 1916 and by an international court in 1933. Denmark could also conceivably claim an Arctic sector $\left(60^{\circ} \mathrm{W}\right.$ to $\left.10^{\circ} \mathrm{W}\right)$.

10 Norway ratifies the UNCLOS on June 24, 1996; Russian Federation ratifies the UNCLOS on March 12, 1997; Canada ratifies the UNCLOS on November 7, 2003 ; Denmark ratifies the UNCLOS November 16, 2004.

11 Where a State establishes the outer edge of its continental margin by applying the method set forth in the preceding paragraph of this statement, this method may also be utilized by a neighboring State for delineating the outer edge of its continental margin on a common geological feature, where its outer edge would lie on such feature on a line established at the maximum distance permissible in accordance with article 76 , paragraph 4 (a) (i) and (ii), along which the mathematical average of the thickness of sedimentary rock is not less than 3.5 kilometers.

12 In accordance article 76 incl. paragraph 4 (a)(i) and (ii).... either shall not exceed 200 nautical miles where the outer edge of the continental margin does not extend up to that distance ... or 350 nautical miles from the baselines from which the breadth of the territorial sea is measured or shall not exceed 100 nautical miles from the 2,500 meter isobaths, which is a line connecting the depth of 2,500 meters. 
boundaries used drawn hypothetical boundaries which could be found in different publications and on the web. We also suggest an approximate perception of the Arctic borders position based on the maximum furthest outer boundaries from baselines, current agreements and claims, and on the principle of equidistance, accuracy of which are defined by the map scale. It is obvious that if we used maximum criteria of the width of CS delineation, it would leave the distinct polar enclave drawing on the map. However, coastal countries did not begin to define coordinates of the shelf outer boundary within $4^{-5}$ articles 76 , but claimed submarine ridges that by UNCLOS are 'natural components of the continental margin' in the spaces of the seabed where they meet the criteria applied to submarine elevations through the second sentence of Article 76(6), in as much as the morphological ridgelike features are included in the definition of submarine elevations according to common and accepted formal definitions of submarine seafloor.

\subsection{Historic Claims over the Arctic and State Practice on Delimitation of the Continental Shelf \\ 2.3.1 Review of Historic Claims over the Arctic}

On December 20, 2001 Russia delivered submission to the CLCS claiming that the Lomonosov Ridge was an extension of its continental shelf. Russia stood to potential acquisition of nearly one-half of the Arctic Ocean, including the North Pole. In 2002, the UN Commission neither rejected nor accepted the proposal, recommending an additional research was necessary. On August 4, 2015, Russia resubmitted its bid, containing new arguments based on the new scientific data collected in years of Arctic research. ${ }^{13}$

On November 27, 2006, Norway made an official submission into the CLCS and provided arguments to extend the Norwegian seabed claim beyond the $200 \mathrm{~nm}$ in three areas of the northeastern Atlantic and the Arctic: the 'Loop Hole' in the Barents Sea, ${ }^{14}$ the Western Nansen Basin in the Arctic Ocean, and the 'Banana Hole' in the Norwegian Sea. ${ }^{15}$ On March 27, 2009, Norway received recommendations from the CLCS with the advice to clarify territorial disputes in the Barents Sea, Arctic Ocean, Norwegian and Greenland Seas. The CLCS

\footnotetext{
13 Through this bid, Russia is claiming 1.2 million square kilometers (over 463,00o square miles) of Arctic sea shelf extending more than $35^{\circ}$ nautical miles (about $65^{\circ}$ kilometers) from the shore.

14 The delimitation of the continental shelf and the 200-mile zones in the Barents Sea is an essential basis for the exploration and exploitation of petroleum deposits in the area of overlapping claims, which covers an area of 175 ooo square kilometers.

15 The submission also states that an additional submission for continental shelf limits in other areas may be posted later.
} 
also acknowledged that the information for the Loop Hole contained in the Submission of Norway of 27 November 2006 fully satisfies the requirements of a submission for continental shelf beyond $200 \mathrm{M}$ from the territorial sea baselines of Norway in accordance with article 76, paragraph 8 , and article 4 of Annex II to the Convention. Only a bilateral delimitation between Norway and the Russian Federation remained to be carried out to delineate the extent of each coastal State's continental shelf in the Loop Hole. ${ }^{16}$ The Commission recommended that Norway proceed with the delimitation of the continental shelf beyond $200 \mathrm{M}$ in the Loop Hole by agreement with the Russian Federation with the assurance that both coastal States share entitlement to the seabed and subsoil located beyond $200 \mathrm{M}$ in this part of the Barents Sea as the natural prolongations of their land territories.

The Commission recommended to Norway that, in accordance with article 84 of the Convention, upon entry into force of a maritime boundary delimitation agreement with the Russian Federation in the central Barents Sea, it deposit with the Secretary-General of the United Nations charts, or a list of geographical coordinates of points, showing the line of delimitation of the continental shelf beyond 200 nautical miles.

On December 15, 2014, the Kingdom of Denmark submitted to the CLCS in respect of the Northern Continental Shelf of Greenland, to attempt to prove that the Lomonosov Ridge is an extension of Greenland's land mass.

On 6 December 2013, Canada made its own submitted to the CLCS.

In sum, currently, Canada, the Kingdom of Denmark and the Russian Federation assert that the Lomonosov Ridge is a continuation of their own continental shelf, while the US claims it to be an oceanic ridge and thus not an extension of any State's continental shelf.

The provisions of Article 76 do not prejudice the question of delimitation of the continental shelf between States with opposite or adjacent coasts. In Arctic, continental shelves of coastal countries are adjacent and, according to Article 83 UnCLOS, delimitation should be carried out on the grounds of agreement based on international law in order to reach a fair decision. However, this formula has not always been working, and each country has its own history of polar claims and methods of delimitation.

16 The same approach has been taken to the delimitation of the continental shelf and the fisheries zones in the area between Greenland and Svalbard, which has now been settled, and to the delimitation of the continental shelf in the Norwegian Sea. It is also being used in dealing with the unresolved questions related to the delimitation line between Norway and Russia in the Barents Sea. 
In February 1907, Canadian Senator Pascal Poirier proposed a resolution before the Canadian Senate to declare possession of the lands and islands between Canada and the North Pole. 18 years later, in June 1925, Canada became the first State to claim that its boundaries extended into to the Arctic and up to the North Pole by adoption Amendment to the Northwest Territories Act. Less than a year after President Truman established Proclamation 2667, ${ }^{17}$ Canadian Ambassador to the US Lester Pearson, attempted to claim not only the islands, but the frozen sea north of the mainland between the meridians of Canada's east and west boundaries, extending up to the North Pole under Canadian sovereignty. Canada became the first country to extend its maritime boundaries based on the 'Sector principle' (between $60^{\circ} \mathrm{W}$ and $141^{\circ} \mathrm{W}$ ).

In 1910-1915, Russia claimed territorial sea to $12 \mathrm{~nm}$ and organized Arctic Ocean Hydrographic Expedition, the first ever traverse of the Northern Sea Route. It represented a great effort by the Imperial Russian Navy to explore, survey, and chart the Northern Sea Route for commercial purposes. On 15 April 1926, Union of Soviet Socialist Republics (USSR) issued its 'Arctic Decree' where declared sovereignty over all lands and islands (including those that may be discovered in the future) between the USSR and the North Pole. The Decree was seen as a response to previous Canadian claim to the territory between its mainland and the North Pole the previous year. In 1926, Russia fixed its claim in Soviet law (between $3^{\circ} 04^{\prime} 35^{\prime \prime} \mathrm{E}$ to $168^{\circ} 49^{\prime} 30^{\prime \prime} \mathrm{W}$ )..$^{18}$

By a 2004 Norwegian legislation, the breadth of the territorial sea has been increased from 4 to $12 \mathrm{~nm}$ for mainland Norway, Spitsbergen and Jan Mayen. In 2005, this was also implemented for Bouvet Island. In connection with the extension of the territorial boundary in 2004, the EEZ extended to $200 \mathrm{~nm}$ beyond the baseline. Where there is less than $400 \mathrm{~nm}$ to another state's baseline, the zone is delimited by the agreed demarcation lines between the states. ${ }^{19}$ In a legal sense, the Norwegian continental shelf is the seabed from the territorial boundary at $12 \mathrm{~nm}$ from mainland Norway, Svalbard and Jan Mayen

17 In his proclamation (July 1946), President Truman sought to preserve and utilize the natural resources of the subsoil and sea bed of the continental shelf (beyond the 3-mile limit) beneath the high sea that extended from the United States' shores, affirmed that the United States had exclusive jurisdiction over its continental shelf resources.

18 Norway $\left(5^{\circ} \mathrm{E}\right.$ to $\left.35^{\circ} \mathrm{E}\right)$ made similar sector claims - as did the United States $\left(170^{\circ} \mathrm{W}\right.$ to $141^{\circ} \mathrm{W}$ ), but that sector contained only a few islands so the claim was not pressed.

19 At Svalbard a fish protection zone has been established. This is calculated in the same manner from the baselines of the Svalbard archipelago. The zone is limited by the outer boundary of Norway's economic zone and agreed demarcation lines towards Greenland and Russia. 
and out to the outer limits of the continental shelf or agreed demarcation line against another state.

\subsubsection{The 2010 Delimitation Treaty between Norway and Russia}

Norway and Russia have a longstanding delimitation history. ${ }^{20}$ In the course of the fifteen to eighteenth centuries coastal border spaces between Norway and Russia did not have official delimitation and got their names 'common areas' (fellesdistrikter). ${ }^{21}$ These areas remained the areas of common use for more than five centuries. ${ }^{22}$

In 1825, demarcation of the border was carried out in 'common area' which was 4,4 thousand of square $\mathrm{km}$, according to Norwegian maps, and which was later owned by the Swedish-Norwegian Union for various reasons. Demarcation was acknowledged by the Convention 'Borders between Russia and Norway in the area of Lapland pogost', signed in 1826 .

In $1871-1872$, the united government of Sweden and Norway exchanged memoranda with the Russian government, where the equality of all states in the use of Spitsbergen natural resources was acknowledged. Reasonability of research work implementation in archipelago was acknowledged, the idea of exclusive ownership of the archipelago by one of the states was denied. International legal status of Spitsbergen as a terranullius was defined by the Convention. Actually, up to the adoption of the Convention about Spitsbergen in 1920 the stated territory was in common use by the states. Historically it resulted in the international practice of peaceful economic and scientific use of Spitsbergen transformed into custom and legally adopted in $1871-1872$. This treaty was called 'Spitsbergen treaty of 1872 '. ${ }^{23}$

In spite of the ratified agreement between the USSR and Norway about the marine borderlines between the two countries signed on February 15 1957, the negotiations about economic zones and continental shelf boundaries in the Barents Sea did not stop. From the very beginning of the official negotiations, ${ }^{24}$

20 The first reference of the contractual design of bilateral relations belong to the XIII century. In 1251, the first agreement on the settlement of relations in border areas between Russia (Novgorod) and Norway was concluded. In 1326, the agreement 'On Eternal Peace' was concluded between the Novgorod Republic and the Swedish-Norwegian king Magnusom-Erikssonom, which fixed the actual existing border.

21 This territory included three counties along the river Neiden (Nyavdem) Pasvig (Pazrek) and Pace (Pechenga) with settlements of three groups of East Sami (Skolt).

22 L.M. Poval Russian-Norwegian agreement on the division of the Arctic spaces. Arctic and North. 2012 №6.

23 Dekanozov R.V. 1872 Agreement on Svalbard - Questions of Soviet legal theory. Novosibirsk, 1968. p. 133.

24 From 1974. 
the Soviet Union and Norway had fundamentally different standpoints and no willingness to compromise. ${ }^{25}$ But on September 15, 2010 Norway and Russia signed a treaty on maritime delimitation and cooperation in the Barents Sea and the Arctic Ocean. ${ }^{26}$ By the agreement, the Barents Sea is fully enclosed by the 200-nautical-mile limits of the Spitsbergen Archipelago to the northwest, the Russian Franz Josef Land and Novaya Zemlya to the north and the east, and the adjacent mainland coasts of Norway and Russia to the south. ${ }^{27}$

The 2010 Agreement ${ }^{28}$ defines the maritime delimitation line by eight points and splits the disputed area nearly in half. The underlying calculation accounts for the longer Russian coastline, but other factors Russia invoked earlier do not seem to have influenced the boundary line. The northern terminal point of the delimitation line is defined as the intersection of the line drawn through points 7 and 8 and the line connecting the easternmost point and the westernmost point of the still undefined outer limits of the states continental shelves.

Thus, we can state that even the coastal countries agreed to apply to the Arctic spaces 'delimitation tools' of UNCLOS, they are not very much succeeded in overcoming disagreements on its implementation. In retrospect, we can turn to the initial Canadian offer of 1925, followed by the Russian government regulation of 1926, Russian-American delimitation line adopted in 1990, the Norwegian offer dating 1975 which proposed geometrical delimitation based on sector division; so we cannot leave this method to oblivion due the fact that it gives the choice of the delimitation method by the countries having opposite and adjacent coasts.

The Russian-Norwegian agreement is the unique example of compromising which does not offer a widely recognized methodology to resolve all disagreements on delimitation issues which have to turn our attention to the other Arctic states policy and implementation practice.

25 Between the two states' preferred borderlines, lay a disputed area of 176 'ooo square $\mathrm{km}$. with rights to exploit the resources unsettled. The disputed area made up 12 percent of the whole Barents Sea, which is the equivalent of 45 percent of Norway's total land area.

26 Treaty between the Kingdom of Norway and the Russian Federation concerning Maritime Delimitation and Cooperation in the Barents Sea and the Arctic Ocean, Nor-Russ., Sept. 15, 2010, available at http://www.regjeringen.no/upload/UD/Vedlegg/Folkerett/avtale_engel sk.pdf.

27 From the very beginning of the official negotiations in 1974 the Soviet Union and Norway had fundamentally different standpoints and no willingness to compromise. Between the two states' preferred borderlines, lay a disputed area of $176^{\prime}$ 'ooo square kilometres with rights to exploit the resources unsettled. The disputed area made up 12 percent of the whole Barents Sea, which is the equivalent of 45 percent of Norway's total land area.

28 The delimitation line between Norway and Russia in the Barents Sea, agreed in 2010 and effective from 7 th July 2011. 


\section{Respective National Strategy of the Arctic Coastal} States in the Arctic

\subsection{U.S. National Strategy in the Arctic}

In the USA there is a good deal of documents forming the national strategy in the Arctic. ${ }^{32}$ Under the US legislation, the US Arctic strategy is supposed to be implemented in a manner consistent with the Constitution and laws of the United States, with the obligations of the United States under the treaties and other international agreements to which the United States is a party, and with customary international law as recognized by the United States, including with respect to the law of the sea. The key term here is 'recognized' and if not, the decision could be based only on the current state interests.

In accordance with the current policy, it is declared by the US pretty much the same objectives as similar documents issued by other countries: protect the Arctic environment and conserve its biological resources; ensure that natural resource management and economic development in the region are environmentally sustainable; strengthen institutions for cooperation among the Arctic nations; involvement the Arctic's indigenous communities in decisions that affect them and enhance scientific monitoring and research into local, regional, and global environmental issues. Nothing we can find in those documents related to the seabed delimitation.

Most of the $\mathrm{NSD}^{29}$ were adopted in the US by the president G.W. Bush administration (2009). Under President B. Obama, the administration announced its own vision on 'Arctic strategy' $(2013)^{30}$ and adopted final rules that require companies working in the offshore Arctic to put in place new safety precautions to prevent and contain oil spills in the remote and forbidding region. ${ }^{31}$ Even the US NSD are not very much concrete with regard to the future delimitation policy, we can find some useful provisions:

\footnotetext{
29 National Security documents.

3o Not many deviations from the previous strategy.

31 The rules are rooted in part in the administration's experiences with Royal Dutch Shell, which encountered a series of setbacks when it pursued exploratory drilling in the Arctic in 2012 and 2015.Under the Bush Administration, roughly 80 million acres in Arctic waters were opened to energy development as part of the 2007-2012 offshore drilling plan. Six sales were planned, but only one occurred - Chukchi Sea Lease Sale 193 - before the DC Circuit Court of Appeals declared the plan illegal. Numerous companies, including Shell, acquired leases for exploration in the Chukchi Sea off the Alaskan Coast. In March 2010, the Obama administration cancelled all future lease sales in the Arctic Ocean, citing a lack of information to support moving forward, but kept the three million acre Chukchi Lease Sale 193 intact, amounting to nearly usD $\$ 2.7$ billion.
} 
(1) In respect of Extended Continental Shelf and Boundary Issues ... "the most effective way to achieve international recognition and legal certainty for our extended continental shelf is through the procedure available to States Parties to the U.N. Convention on the Law of the Sea."

(2) For unresolved boundary in the Beaufort Sea, the United States policy recognizes a boundary in this area based on equidistance."

(3) For the US-Russian boundary the United States expect that the maritime boundary treaty concluded in 1990 will come into force. ${ }^{32}$

From all these we can draw following conclusions: for the US the Arctic region is primarily a maritime domain for which existing policies and authorities relating to maritime areas continue to apply, including those relating to law enforcement and the government will take all actions necessary to establish the outer limit of the continental shelf appertaining to the United States, in the Arctic and in other regions, to the fullest extent permitted under international law, without clear definition what should be understood by this term.

\subsection{Russia's Strategy in the Arctic}

The main goals, strategic priorities and the Russian Federation state policy mechanisms of implementation in the Arctic for the period up to 2020 and further prospects are defined in "The foundation of the state policy of the Russian Federation in the Arctic' ${ }^{33}$ Both the American doctrine and this document contain pretty much common provisions about strengthening of the bilateral efforts of the region countries and within regional organizations like the Arctic Counsel and Barents/Euroarctic region Counsel; provisions of good-neighborly relations with coastal states, the development of economic, research, cultural cooperation including the field of effective development of natural resources and environment protection in the Arctic; improvement of living conditions of native population and social conditions for economic activity in the Arctic.

Above all these this document states that a strategic priority of Russian policy in the Arctic is the implementation of cooperation between Russia and coastal states in order to delimitate marine spaces on the basis of International Law, mutual agreements taking into account national interests of the Russian Federation and also to decide matters on International legal justification of the outer border of the Arctic zone of the Russian Federation; ${ }^{34}$ delimitation of marine spaces in the Arctic Ocean and the provision of mutually beneficial

32 NSC-26, “D”.

33 Approved by the President of the Russian Federation of September 18, 2008 N Pr-1969.

34 Paragraph 7(a) Russian Arctic state policy adopted in 2008. 
presence of Russia on Spitsbergen archipelago. ${ }^{35}$ All mentioned provisions concerning delimitation don't seem exact with the exception of Spitsbergen; although in Article 9 of the document the main state Russian policy goals in the Arctic can be reached on the basis of the preparation of Russian legal acts on the defining of the geographical borders of the Russian Federation in the Arctic. ${ }^{36}$

\subsection{Norwegian Strategy in the Arctic}

On December 1, 2006 the Norwegian Government releases its 'High North Strategy' to clarify long-term Norwegian policy in the Arctic "in order to secure economic resources and its security into the future."37 It was stated in the document that one of the government's most important priorities in the years ahead will be to take advantage of the opportunities in the High North. The term 'to take an advantage of the opportunities' is not determining, but brief objectives of Norway High North strategy are following:

- continue to build on good neighborly relations with Russia;

- continue to exercise responsibility for combating illegal fishing and managing the renewable fish resources for present and future generations;

- take advantage of the opportunities the Barents Sea presents as a new European energy province in accordance with the principles of sustainable development;

- take environmental and climate considerations into account in all state efforts;

- improve living conditions, opportunities and the quality of life for all those who live in the High North. ${ }^{38}$

Actually, each A-5 country could sign mentioned above provisions as its own and all countries declare that would like to sea not only Barents Sea, but the whole Arctic as a 'ocean of cooperation'.

What Norway consider as the 'conflict of interest' - related to the utilization of fisheries resources and future offshore petroleum resources. ${ }^{39}$ Probably, from real practice one should read the Norway Arctic strategy more expanded. One of the issue is the differing views on the geographical scope of the Spitsbergen

\footnotetext{
35 Paragraph 7(e) Russian Arctic state policy adopted in 2008.

$36 \quad$ Paragraph 9(в) Russian Arctic state policy adopted in 2008.

37 The Norwegian government's High North strategy, p. 1-18 https://www.regjeringen.no/en/ dokumenter/strategy-for-the-high-north/id448697/.

38 The Norwegian government's High North strategy, p. 5 https://www.regjeringen.no/en/ dokumenter/strategy-for-the-high-north/id448697/.

39 The Norwegian government's High North strategy, p. 16 https://www.regjeringen.no/en/ dokumenter/strategy-for-the-high-north/id448697/.
} 
Treaty. Norway's position that the treaty, in accordance with its wording, only applies to the archipelago and the territorial waters. Spain, Iceland and Russia have disputed this right with reference to the provisions of the Spitsbergen Treaty.

It was also stated that Norway's policy towards Russia is based on pragmatism, interests and cooperation. Norway ensure sustainable use of resources and sound environmental management in the Barents Sea with Russia's engagement and Norwegian-Russian cooperation. The Government therefore intends to strengthen cooperation with Russia on ecosystem-based management of the whole Barents Sea, both in the Joint Norwegian-Russian Commission on Environmental Protection and in the Joint NorwegianRussian Fisheries Commission. This cooperation includes measures to combat illegal, unreported and unregulated fishing.

As it was further written, developing close cooperation with Russia on sound exploitation of the petroleum resources in the Barents Sea should be Norwegian government ambition and both the former and present Norwegian Government accepted President Putin's invitation to forge a strategic partnership between Norway and Russia in the North, but in reality looks rather doubtful. Much more realistic looks Norwegian ambitions of the future role of the Norwegian Armed Forces with obligations to:

- strengthening capacity of the Coast Guard vessels and the Orion aircraft to spend more time at sea and in the air, respectively;

- provide more close cooperation between the civilian and military authorities;

- provide background information for national decision-making through up-to- date surveillance and intelligence;

- maintain the presence of the Norwegian Armed Forces in the High North both to enable Norway to exercise its sovereignty and authority and to ensure that it can maintain its role in resource management.

\subsection{Canada's Strategy in the Arctic}

Canadian Arctic strategy was adopted in 2009 and its main provisions are very similar to all other A-5 countries and focuses on four priority areas: exercising our Arctic sovereignty; promoting social and economic development; protecting the North's environmental heritage; and improving and devolving northern governance, so that Northerners have a greater say in their own destiny. ${ }^{40}$ Making more colorful statements like that: the Government of Canada

40 Canada's Northern Strategy: Our North, Our Heritage, Our Future. Published under the authority of the Minister of Indian Affairs and Northern Development and Federal 
is firmly asserting its presence in the North, ensuring we have the capability and capacity to protect and patrol the land, sea and sky in our sovereign Arctic territory. We are putting more boots on the Arctic tundra, more ships in the icy water and a better eye-in-the-sky ${ }^{41}$ in the same time for our object we can find very little except that Canada dealing with Arctic problems will use cooperation, diplomacy and international law as Canada's preferred approach in the Arctic. ${ }^{42}$

What is more important that Canada claims rights in its continental shelf under the 1997 Oceans Act, where adopted the default length of Canada's continental shelf extends to 200 nautical miles from the straight baselines. On December 6, 2013 Canada made partial submission to the CLCS in respect of Atlantic ocean, continuing the data collection for the Arctic spaces. ${ }^{43}$ The dispute in the Beaufort Sea concerns the maritime extension of the land boundary between Yukon and Alaska will certainly influence further delimitation negotiations, which will be under undoubtedly pressureof the assumptionthat the area is considered to be resource-rich. Canada claims that the maritime boundary runs along the 141st meridian as an extension of the territorial boundary agreed with the United States. However, the United States rejects this position, arguing that the boundary must be determined by using the equidistance principle - a recognized mode of maritime delimitation that traces a line at equal distance from the closest land point of each state. This produces a line that reflects more closely the direction of the respective coast lines. Canada and the United States are in effect both promoting the use of a delimitation method that will best serve their respective interests and that will produce, from each of their perspectives, the largest maritime zone possible. Resolution of this dispute is still pending.

Interlocutor for Métis and Non-Status Indians Ottawa, 2009 (http://www.northernstrat egy.gc.ca/cns/cns-eng.asp).

41 http://www.northernstrategy.gc.ca/cns/cns-eng.asp.

42 The US and Canada on January 11, 1988 signed the Agreement on Arctic Cooperation between two states. Following the United States Coast Guard Polar Sea's crossing of the Northwest Passage without formal Canadian governmental consent, the Canadian government established straight baselines around Canada's perimeter.

43 Canada is expected to submit a claim to the CLCS, within UNCLOS, to prove the Lomonosov Ridge is a continuation of its own continental shelf.

Canada is expected to claim that the ridge is an underwater extension of Ellesmere Island. If it's proven that the Lomonosov Ridge is an extension of Canada's continental shelf, Canada would obtain unfettered access beyond their EEZ of 20onm, and instead, would gain access to the seabed and its resources across the continental shelf. Canada would be required to submit bathymetry, seismic and gravity data to substantiate its claim. 


\subsection{Denmark's Strategy in the Arctic}

Within the 2011 'Kingdom of Denmark: Strategy for the Arctic 2011-2020,' Denmark asserts that it will submit data and other material to the CLCS as a basis for extension of the continental shelf beyond 20onm on three areas near Greenland, including the Lomonosov Ridge. Proof that the Lomonosov Ridge extends from Greenland's continental shelf would give Denmark unfettered access to much of the seabed surrounding the North Pole.

On December 17, 1973 Canada and the Kingdom of Denmark sign the agreement on the delimitation of the continental shelf between Greenland and Canada. ${ }^{44}$ The agreement was designed to distinguish territory for the purposes of exploration and exploitation of the natural resources of the continental shelf. Two countries agreed to divide the ocean floor between Canada and Greenland using a median or 'equidistance' line. ${ }^{45}$ Both delayed any decision regarding the sovereignty of Hans Island. ${ }^{46}$ The treaty also has provisions concerning the possible discovery of hydrocarbons along or near the boundary - neither Party shall issue licenses for exploitation of mineral resources in areas bordering the dividing line without the prior agreement of the other Party as to exact determination of the geographic co-ordinates of points of that part of the dividing line bordering upon the areas in question. ${ }^{47}$

This provision of the agreement makes its legal value in the CS resources exploitation of the void. Article v, of mentioned above agreement, created pretty less critical model of the relations by simple formula: if any single geological petroleum structure or field, or any single geological structure or field of any other mineral deposit extends across the dividing line is exploitable, wholly or in part, from the other side of the dividing line, the Parties shall seek to reach an agreement as to the exploitation of such structure or field. In other words, this formula does not solve problem and postpones its decision to the occurrence of a particular dispute for resource exploitation.

44 Agreement between the Government of the Kingdom of Denmark and the Government of Canada relating to the Delimitation of the Continental Shelf between Greenland and Canada (17 December 1973).

45 A line that at every point is an equal distance from the nearest point on each of the two opposing coasts. In this case 109 'turning points' of the 127 were agreed.

46 The agreement distinguished territory between Canada and Greenland. Both delayed any decision regarding the sovereignty of Hans Island - a small 1.3 square kilometer uninhabited island in the Kennedy Channel of the Nares Strait between both Canada's Ellesmere Island and northern Greenland. Both Canada and Denmark (via Greenland) claim the island that exists on both Canadian and Danish sides of the Strait.

47 Michael Byers \& James Baker. International Law and the Arctic. Cambridge University Press University Printing House, Cambridge CB2 8BS, United Kingdom, p. 30, 2014. 
Both countries agreed in 1984 to extend the work to clarify the computation of the equidistance line $\mathrm{e}^{48}$ south of $75^{\circ} \mathrm{N}$ which came to an end in 2003 . Amendment to the coordinates will be provided in several data and may reduce the number of turning points of the boundary from the present 113 points (south of $75^{\circ} \mathrm{N}$ ).

\subsection{Conclusions}

What conclusions can be drawn on the basis of the Arctic delimitation policy? Despite the fact that the several coastal States have concluded bilateral agreements governing the territorial delimitation they did not completely solve the problem of the seabed delimitation.

Canada, the Kingdom of Denmark (via Greenland), and the Russian Federation each assert that the Lomonosov Ridge is an extension of their own continental shelf. Proof of its continuation, would give the State access to the sea bed and natural resources beyond the current $200 \mathrm{~nm}$ limit. The United States claims it to be an oceanic ridge and thus not an extension of any State's continental shelf, and therefore refutes any claim to its ownership.

There is a dispute between Canada and Denmark about delimitation line at Hans Island and in the Lincoln Sea, challenges Lomonosov and claims the USA the direction of the sea border line in the Beaufort Sea.

In 2015, Russia delivered another submission to the CLCS once again claiming the extension of its continental shelf, which stood to potentially acquire nearly one-half of the Arctic Ocean.

The border line with the USA is shown as a direct line coinciding with 'the western limit' in the Article 1 of the Russian-American agreement of 1867 on the Alaska Purchase which comes through the point in the Bering Strait (65 degrees, 30 minutes) in its crossing with the meridian at equal distance of the Kruzenshtern Isle from the Ratmanov Isle, and goes along the unlimited line towards the North until it's fully lost in the Arctic ocean ...49 The Russian-American agreement of $1990^{50}$ 'clarified' the delimitation point and stated that the border in the Bering Strait and further in the Chukchi sea goes along the meridian $168^{\circ} 58^{\prime} 37^{\prime \prime} \mathrm{W}$ up to the limits until it's allowed by International law. It may be admitted that the agreement of 1990 states the delimitation line but it's obvious that it is not enough for the seabed delimitation; if we try to find the outer delimitation point in the Chukchi sea on the

48 The Canadian maps and charts were drawn on the North American Datum (NAD) 1927 and the Danish maps and charts on the Qornoq Datum which uses a different ellipsoid.

49 Full complete Collection of Laws of the Russian Empire. II. Volume XLII. Dep. 1. 1867.

5o The Soviet-American agreement on the maritime border by June 1, 1990. 
principle of equidistance, ${ }^{51}$ it will be located a bit to the west from the straight line connecting the delimitation point in the strait and the North Pole which used to be drawn on the majority of presentation maps and in some official sources.

Except ostentatious, in our view, pretentiousness coastal states policy, there is another problem which affects the possibility to deal with coastal countries contradictions. Despite the fact that practically all of them tend to stress the necessity to turn the Arctic into the 'peace zone', their military presence in the region is escalated, and there is typical reasoning that polar regions are both vital from economic, ecological point of view, and for the reasons of national security.

On the one hand, all countries' claims are equally categorical in the region; on the other hand, opportunities to provide military presence in the Arctic coastal regions are different.

The USA is the only country which didn't ratify UNCLOS; anyway, it can't be the sign of the drawback of legal policy of the state which has been defining and clarifying its Arctic national interests since 2004. In terms of strategy implementation there are at least 3 main points:

- to make every effort to provide national security;

- to joint efforts with other coastal states within both NATO and the Arctic Counsel keeping the possibility of other unions;

- to maintain the freedom of navigation according to the norms of International Law.

As these are the points from the strategy 'open' part', it may be presumed that the real 'joint effort' is nothing but actions within traditional military alliances, and there is no doubt that the USA wouldn't really tend to cooperate with at least one country among the region states. It is most likely that the last point concerns the efforts to give the Northern sea route the status beyond the laws drawn by the Russian Federation.

The USA does not have big military-industrial bases on the Arctic coast with the exception of temporary base in Barrow which can be regarded as a small base rather than a Navy base. It's obvious that in order to solve problems maintaining the US interests in the Arctic by force which are also connected with the resource extraction activities, will demand the deployment of the Pacific forces command. This fact makes the idea of attracting of the allies owing coastal infrastructure very appealing, what actually are doing the USA getting involved into military cooperation North-European countries within NoRDEFCo (Nordic Defense Cooperation).

$5^{1}$ This is not the only method, and is cited as an example. 
Canada, as well as Denmark, does not have ground forces in the Arctic zone. Nevertheless, the Canadian government builds so-called 'hubs' there (North Operations Hubs, $\mathrm{NOH}$ ). Such first hubs were built in Resolute Bay and Iqaluit (the south-east of the Baffin Island), and by 2018 the Canadian Navy ships fuelling point is being planned to be constructed in Nanisivik (North-western part the Baffin Island).

Norway actively supports the NATO 'Arctic vector', and was one of the initiators of 'the NATO Arctic strategy' (January 2009), promotes Scandinavian countries' efforts to create a special security zone, already given the name 'mini-NATO - creation of the defense alliance' of 5 states - Denmark, Iceland, Norway, Finland and Sweden to strengthen their military position in the Arctic.

Russia is the only country which has not only permanent military bases but nuclear forces, military infrastructure objects, including the unique shipbuilding and other industrial enterprises. This complex was formed long ago since the surge of interest to the Arctic. ${ }^{52}$

In response to strengthen the military activity in the Arctic, Russia in 2014 announced about the creation of the Arctic forces within the frames of the North fleet, ${ }^{53}$ in 2016 the decision was made to locate special subdivisions in Chukotka. The location of military objects is carried out not only in traditional places of Archangelsk and Murmansk regions, but on the islands - Novaya Zemlya and Franz Josef land, 'polar trainings' have begun more active.

Above all this, Russia has started to use military objects in the peaceful purposes by attracting military personal and staff for the research work. The example is mutual efforts at the station 'Barneo', not far from the North Pole. ${ }^{54}$ Moreover, infrastructural objects 'GLONASs' and 'Iss' 'Arctica'; 55 communication systems to navigate ships and aircraft on cross-polar routes, ${ }^{56}$

$5^{2} \quad$ The first Naval ships in the North of Russia were built under Peter I, and the first regular Flotilla was formed in 1916 and was named the 'Flotilla of the Arctic Ocean,' which in September 1917 included 89 combat and support ships. In 1937, the Flotilla transformed into the Northern Fleet.

53 "The Northern Fleet - United Strategic Command" (sF-USC) with the of 'military district'.

54 Drifting base 'Barneo' is created in the Arctic every year. Such an object can be attributed to the objects of dual-use, which could be recognized as novelty in the practical development of the Russian Arctic.

55 Mss 'Arctica' is composed of three sub-systems intended for hydrometeorological and climate ('M') monitoring; radar monitoring ice conditions (" $\mathrm{P}$ ") and provide satellite communication and navigation 'MS'). In the nearest future with the cable laying 'Polarnet System' it will be incorporated to the 'United information space of the Arctic zone of the Russian Federation'.

$5^{6}$ Flights of this type operate 11 airlines, including Russian, Canadian, American and Chinese. 
reconstruction of the research objects on the islands of archipelago Severnaya Zemlya, rebuilding of the northern aerodromes (Tiksi, Naryan-Mar, Alykel, Amderma, Nagurskaya, Anadyr and Rogachevo)... are also on 'military shoulders'.

All these facts may serve only as positive circumstances but they cannot change general tendency to militarization of the Arctic, which make chances to compromise pretty low.

\section{$4 \quad$ Addressing and Solving Conflicts regarding Seabed in the High North}

So, we may make presentations at international forums, assemblies, sessions of the Arctic counsel assure each other in peaceful intensions, but the fact is - there is no real peace in the Arctic - rivalry is escalated, and all states of the region are not prepared to compromise defending their national interests. Adding the traditional 'NATO spice' on top of that, increase of military trainings in the Arctic zone, already exceeding the level of the cold war, active involvement of Iceland, Finland and Sweden in military games ${ }^{57}$ adding to this Russian efforts in strengthening its Northern fleet, which includes the nuclear component the conclusion on unfavorable political and legal environment is quite obvious.

Now, my experienced reader, ask yourself a question - what peaceful methods must be chosen to resolve present delimitation contradictions. Although the conclusion about the need to reduce the intensity of the 'struggle for the Arctic resources' although trivial, but it is the ground of all other efforts. And what delimitation methods would be chosen its implementation in reality without establishing political warming in Arctic seems to be useless. In addition, the principle question whether the Arctic coastal states have to have the same level of responsibilities in the spaces beyond the $200 \mathrm{~nm}$ limits as the non-regional states remains unanswered. Formula "apply UNCLOS and enforce freedoms granted by the Convention" without considering the peculiarities of the region,- is completely irresponsible decision.

What could be the principles for the seabed delimitation in Arctic? Theoretically states have three options: to follow the provisions of the UNCLOS, to create specific regime outside UNCLOS frames by bilateral agreement or

57 It is known that the United States, Canada, Norway, Finland, Sweden, Denmark and Iceland propose to create a military group of the rapid response, including ice-breaking ships, amphibious units and air forces. 
keep talking maintaining sluggish negotiations or by using the delimitation disputes for periodic outburst of political activity in the region.

A-5 agrees to apply international law provisions for activity in the Arctic Ocean with regard to the delimitation of the outer limits of the continental shelf the coastal states should recognize their obligations and responsibilities under the Law of the Sea in the Arctic, including their commitment to the orderly settlement of any possible overlapping claims.

A- 5 also agrees that the provisions of the UNCLOS should be the legal base for the resolving the Arctic claims ${ }^{58}$ particular Article 83, which relate to the continental shelf delimitation agreements which are to be based on international law and the uniform geodetic coordinate system ${ }^{59}$ to achieve an equitable solution.

In all cases the decisions of the CLCS with adoption of the continental shelf outer limits will need to be delineated on the basis of CLCS recommendations which will be final and binding only after adoption by the coastal states.

The adjacent boundaries were adopted by the three agreements - between Norway and Russia (which is limited by the point 8 ); 60 between Norway Denmark ${ }^{61}$ and Denmark - Canada. The US and Canada have the dispute in the sea of Beaufort and the Arctic boundary between the US and Russia is uncertain.

According to the decisions established by the International Court of Justice, the starting point is the delimitation line should follow the median line between the two states' coastlines. The starting points of the US-Canadian and the US-Russian boundaries are agreed, but the direction of the first one is in dispute, and the second is uncertain. If even the 1990 US-Russian agreement will be ratified the concept 'as far as permitted under international law'62

58 The Ilulissat Declaration was announced on May 28, 2008.

59 As an example - agreement between Canada and Denmark, where from a surveying stand-point, the interesting aspect is the fact that the Canadian maps and charts were drawn on the North American Datum (NAD) 1927 and the Danish maps and charts on the Qornoq Datum which uses a different ellipsoid. The technical experts knew that there was a difference between the geodetic coordinate systems but had no way of knowing the magnitudes. So the practical solution was to set the problem aside for future consideration and to assume that the two coordinate systems were identical.

6o Norway-Russia agreement in the Varangerford area 2007 and 2010 Treaty between the Kingdom of Norway and the Russian Federation concerning Maritime Delimitation and Cooperation in the Barents Sea and the Arctic Ocean.

61 On the delimitation of the continental shelf and the fisheries zones in the area between Greenland and Svalbard 2006.

62 USA-USSR 1990 Agreement. Annex: 'From the Initial point, $65^{\circ} 30^{\prime}$ N., $168^{\circ} 58^{\prime} 37^{\prime \prime}$ W., the maritime boundary extends north along the $168^{\circ} 58^{\prime} 37^{\prime \prime} \mathrm{W}$. meridian through the Bering Strait and Chukchi Sea into the Arctic Ocean as far as permitted under international law.' 
could not be applied for the delimitation of the seabed and subsoil based on the UNCLOS provisions.

In the same time, keeping in mind that the US did not ratified the UNCLOS, based on the customary international law this line could be as far as the agreement between two states will allowed.

In any case, it can be argued that the provisions of the UNCLOS do not prevent the Arctic countries to use bilateral agreements, based on its own method of delimitation, where geographical criteria would greatly simplify the delineation of adjacent spaces up to the Northern Pole. It could also be the ground for an agreement for mutual exploitation of the resources beyond the $200 \mathrm{~nm}$ limits in the Arctic seabed by way of a joint development agreement. Such agreement would enable to mutually share the exclusive rights as regards natural resources in the contested areas without abandoning their claims and also without the need for a final resolution of all legal outer limits delimitation issues. 